\title{
R\&D EXPENDITURE AND THE ROLE OF SCIENTISTS
}

\author{
Anna Białek-Jaworska \\ University of Warsaw, Warsaw, Poland \\ e-mail: abialek@wne.uw.edu.pl \\ ORICD: 0000-0003-4520-8916
}

\author{
Justyna Dobroszek \\ University of Lodz, Lodz, Poland \\ e-mail: justyna.dobroszek@uni.lodz.pl \\ ORICD: 0000-0003-4728-9019
}

(C) 2019 Anna Białek-Jaworska, Justyna Dobroszek

This is an open access article distributed under the Creative Commons Attribution-NonCommercial-NoDerivs license (http://creativecommons.org/licenses/by-nc-nd/3.0/)

DOI: $10.15611 /$ fins.2019.2.01

JEL Classification: O16, O32, O34, M41

\begin{abstract}
An effective knowledge-based economy requires regular cooperation between science and business. This is possible thanks to enterprises that create and implement innovations The paper focuses on the recognition of R\&D expenditure. This aims to verify if firms with a scientist on their board are more likely to invest in the R\&D. We conduct a tobit panel analysis of over 18,000 Polish private firms combined with data on patents and scientists employed at universities. The findings show that firms with scientists on the supervisory board are likely to invest more in R\&D. However, these investment in R\&D of firms with a scientist on the board are financial constraint. Their growth depends on access to finance. Therefore, institutions in Poland should support and promote cooperation between science and business, aiming for the realization of the implementation research. This approach requires updated regulations in the accounting area relating to the recognition of $R \& D$ inputs and outcomes.
\end{abstract}

Keywords: R\&D, dynamic entrepreneurship, academic entrepreneurship, innovation, scientist, family business.

\section{Introduction}

By introducing the Lisbon Strategy and then the Europe 2020 Strategy, the European Union (EU) place great emphasis on knowledge and innovation, which form a knowledge-based economy model (KBE). Poland as a member country of the European Union, also through various circumstances (co-financing of science, co-financing of businesses which will cooperate with scientists, also in form of a special tax relief) is aiming to develop this type of economy. However, apart from the activity of governments, there is the need to activate organizations that should 
become "dynamic enterprises" (in the framework of J. Schumpeter) instead of "stable organizations". The entrepreneurship in the sense of J. Schumpeter means having wide horizons, perceptiveness and will power, so seeking innovations which may have different dimensions, i.e. creating new goods or new production methods, opening new markets, gaining new sources in the supply chain, and a new organization of the economy. All these types of innovations are precisely the result of entrepreneurial activities that lead to the creation of new relationships between resources or changes in them, and result from data or news on the part of producer and client [Enders, Woods 2010]. A special group of entrepreneurs are family businesses due to their long-term investment perspective and particular attitude to the maximising of profit in the short term. Fewer agency problems, thanks to owners (family) engagement in management allow to create new solutions which can be translated into innovation. Searching for innovation is related to expenditure on research and development (R\&D) and - in the case of success - commercialization of research results, which is reflected in the accounting system, including the financial statements. Investments in $\mathrm{R} \& \mathrm{D}$ for commercialization can be increased by entrepreneurs by including scientists in the management/supervisory boards. Thanks to their comprehensive approach and skills in obtaining money and access to academic infrastructure and staff, researchers may encourage businesspeople to carry out research, in particular of an implementation nature. In this way, a knowledge-based economy can be built on the active cooperation between science and business.

The paper aims to verify if companies with a scientist on their management board, in particular family businesses managed by a scientist, are more likely to invest in the R\&D outcomes for commercialization. We focus on the recognition of $R \& D$ expenditure bearing in mind the accounting regulations and consider the following issues: financial constraints, subsidies and IP protection. To achieve the aim of study we created the panel data from the annual reports of Polish companies combined with data from the National Court Register (board members), and data on patents and scientists employed at universities. We benefit from Polish conditions as cooperation between business and science is crucial for innovative economy development in Poland. As a tool we apply the tobit panel analysis based on a sample of 18,125 Polish limited liability and joint-stock companies for 2003-2013.

The findings showed that companies with scientists on their management and/ or supervisory board invest more in $\mathrm{R} \& \mathrm{D}$, this also especially refers to family businesses. Moreover, (1) financial constraints are a more important limitation for R\&D investments of companies with a scientist on their management, (2) important sources of financing of R\&D investment of companies with a scientist on the board are government subsidies for research and infrastructure, (3) it is worth highlighting that such companies increase $R \& D$ expenditures for commercialization of the R\&D outcomes when their growth opportunities decrease.

The remainder of the paper is organized as follows: the second section includes a literature review structured on four relevant topics: KBE and innovation, 
entrepreneurial behavioural and the family aspect, $R \& D$ expenditure, and scientist participation on the board. The literature review is followed by a presentation of the research methodology, as well as by a description of the research sample and findings. The conclusions are presented in the final section.

\section{Literature review}

\subsection{Economy based on knowledge and innovation}

The 21st century is associated with numerous changes in the functioning of economies and businesses. They are the result of transformations of a social, economic, demographic, cultural and technological nature [Bryła et al. 2013]. Particular emphasis was placed on two pillars, i.e. knowledge and innovation. They influenced the creation of the so-called knowledge-based economy (KBE). According to P.F. Drucker [1999] is knowledge and not material resources that are a challenge for economic systems. In order for the KBE to be able to effectively implement specific objectives, it is necessary to harmoniously cooperate on three levels: business, administrative and social [Skrzypek 2011]. Such cooperation is reflected in the accounting system through the recognition of expenditure on R\&D.

The authors define a KBE highlighting either knowledge or innovation. E. Skrzypek [2008] emphasizes that a KBE is an economy in which knowledge creates the production dimension and economic progress. This is defined as an era of 'the knowledge society', because a KBE is based on resources and the application of the potential of knowledge as a strategic development factor. In addition, A. Skrzypek [2009] states that the success factors in a KBE are, among others, quality, knowledge and intellectual capital. A.K. Koźminski [2001] also emphasizes the issue of knowledge, indicating that this category is the determinant of the competitiveness of enterprises in a KBE. Moreover, the OECD together with the World Bank first emphasized the role of knowledge in a KBE, stating that "within its framework knowledge is created, absorbed, transferred and used effectively by various organizations, individuals or communities, thus fostering the dynamic progress of economics and societies" [OECD - World Bank Institute 2000]. The above explanations of the specifics of a KBE reinforce the role of knowledge. However, there are publications that emphasize the importance of innovation. For example, A. Kukliński [2001] defines KBE as a modern model of economic progress based on innovation. However, both terms should not be considered for 'dehumidification'. Knowledge and innovation are closely interrelated because the former is the source for innovation [Koźmiński 2004]. At the same time, to make both categories beneficial for economies, businesses or societies, knowledge should be made available and properly implemented.

The issue of innovation appeared within the framework of the Lisbon Strategy, which assumed innovation as the main source of development of the EU economy. It 
would be created and used as a result of scientific research, especially in the area of advanced technologies. However, new challenges, and the emergence of an economic crisis in the international arena caused the introduction by the UE Commission of the "EU 2020 Strategy", in which one pillar was termed as "intellectual capital". This is important for the categories analyzed above, because it includes innovation, education and IT networks. This pillar delineates the essence of cooperation between science and business, as a result of which innovative solutions are created in the form of products and services that have an economic and social significance [NiklewiczPijaczyńska 2018]. The EU 2020 Strategy is a determinant of the functioning of the Polish economy, where significant financial resources are directed to cooperation between science and business, i.e. R\&D cooperation within scientific consortia and scientific units and enterprises [Perspektywa 2014-2020 ... 2018].

Only on the basis of knowledge and innovation can European countries create smart and sustainable economies. However, a KBE, in order to effectively operate elements such as information and communication technologies, human capital or innovation systems, has to operate properly. As A.K. Koźmiński [2001] points out, building such a model of the economy in the long run requires creating the right conditions for the formation and success of the organization. Enterprises should be willing to cooperate with the scientific community, not only on the basis of mutual cooperation, but also in the form of engaging scientists on management boards of academic spin-offs or spin-outs, but also science employees should be open to relationships with business practice. P. Bryła et al. [2013] indicate the benefits of cooperation between science and business for the scientific community, which are: higher recognition of universities, improvement of education and research quality or financial benefits, and commercialization of research results, access to technical infrastructure of academia or professional and personal development. In turn, business through cooperation with scientists can reduce costs and risks, improve the quality of human capital, get ideas for new solutions and promote their image in the environment.

Effective business relationships with the $R \& D$ organizations certainly affect the innovation and competitiveness of the organization.

\subsection{Entrepreneurial behavioural and family factor}

A KBE is based on innovation, and the initial trend in this direction was initiated by J. Schumpeter [1960]. This concept is related to innovation, that is the range of competences and the ability of a firm to create and implement new products. Three such types are R\&D, non-material and material technology [Drabińska 2012]. According to J. Schumpeter [Brines et al. 2013], innovation is the main source of the entrepreneurial process. This can be verified by assessing how a particular business manages its resources and how it develops production capacity for further innovative solutions. This approach has an impact on changing the economy, and affects its 
development. Thus, entrepreneurship in the sense of J. Schumpeter means having wide horizons, perceptiveness and will power. What distinguishes an entrepreneur from a non-entrepreneur is the departure from the routine and from familiar rules, and the search for something new and its continuous development. Schumpeter described five types of innovation: creating new goods, creating new production methods, opening new markets, gaining new sources in the supply chain, and a new organization of the economy. All these types of innovation are precisely the result of entrepreneurial activities that lead to the creation of new relationships between resources or changes in them, and results from data or new on the part of the producer and the client [Endres, Woods 2010]. In this way, the authors created a profile of the so-called "dynamic entrepreneur", or "change agent", who can find himself/herself in a changing environment. This is a unit that reacts to exogenous factors in given economic conditions and creates endogenously newness by using a creative idea [Endres, Woods 2010]. Such entrepreneurs should be both business organizations regardless of the profile of activity and size, as well as scientific and individual units, i.e. businesspeople and scientists. Only this position can provide a long-lasting and effective model of a KBE.

An important part of the economy of every country are family businesses. In Poland, the percentage of family businesses is around $40 \%$, while in developed countries it exceeds $50 \%$ from the general group of companies [Firmy rodzinne $w$ Polsce... 2018]. There are two factors in family organizations, i.e. business and family. Their combination may foster innovation and entrepreneurship, thus creating new relationships different than in the case of non-family enterprises. [Endres, Woods 2010]. In family organizations there are also other combinations favouring the achievement of innovativeness, which are beyond the family factor, also ownership and management. McCann et al. [2003] stated that the correlation of these variables with business operations increases the efficiency of obtaining innovation. S. Brines et al. [2013] confirmed that the "family" factor has a positive impact on the development of entrepreneurship and innovation.

Business innovation and entrepreneurship can be expressed through spending on R\&D that contain activities carried out continuously in order to increase knowledge. They are associated not only with the search for new solutions, but also with the improvement of the existing processes, products or services in the organization. They are the source of economic growth in line with the new growth theory by Romer [1994] and Lucas [1988]. Therefore, more and more countries pursue policies promoting R\&D activities, particularly at corporate level [Adamczyk 2013]. Schumpeter [1960] points out the importance of self-financing and allocating profits to $R \& D$ activities in the process of raising companies' innovativeness, as is noticed in empirical studies for Poland.

Considering the low amount of recognition of R\&D expenditure in the Polish business accounting system in practice, this aspect will be discussed in the next point. 


\subsection{Expenditure on R\&D}

Enterprises that invest in R\&D incur significant expenditure that, unfortunately, is not recognized in the financial statement nor in the statistics of GUS. As stated by A. Białek-Jaworska [2016], the recognition of R\&D activities in the financial statements results from the adopted strategy specified in the accounting policy. There may be more emphasis on innovation or the commercialization of the research results. Therefore it is necessary not only to distinguish research from development and other form of innovations, but also to recognize the development works in progress in the assets and the disclosure of spending on research and other forms of innovation. In any case, the Polish Accounting Act (PAA) does not define both terms, nor specify which expenditures relate to research and which to development. Such definitions and explanations can be obtained, for example, in the Law on Finance of Science, Research and Development or in The International Accounting Standard 38 (IAS 38). The PAA only allows to recognize expenditure on R\&D, but in intangible assets as costs of completed development works (Art. 3 par. 1 point 14 of the PAA). At the same time, to be able to include them in intangible assets, the conditions referred to in Art. 33 par. 2 of the PAA should be met, according to which the costs of completed development work carried out by the organization for its own needs, incurred before the production or the application of technology, are included in intangible assets if:

1) the product or production technology is strictly established, and their development costs reliably defined,

2) the technical usefulness of the product or technology has been found and properly documented, and on this basis the entity has decided to manufacture these products or apply technologies,

3) development costs will be covered, as expected, with revenue from the sale of these products or the application of technology.

Therefore, the costs of development work will not always be included in intangible assets. They must be incurred before the production or the application of technology and will be covered as expected, by revenue from the sale of these products or the use of technology.

In the case of IAS 38 we can observe a better situation for entrepreneurs in this regard. IAS 38 allows for the recognition of development expenses as intangible assets, if the entity can demonstrate all of the following:

- the technical feasibility of completing the intangible asset so that it will be available for use or sale;

- its intention to complete the intangible asset and use or sell it;

- its ability to use or sell the intangible asset;

- how the intangible asset will generate probable future economic benefits;

- its ability to measure reliably the expenditure attributable to the intangible asset during its development. 
Based on IAS 38 there is no obligation to complete a development project (work, activities) in order to be able to recognize it as intangible assets. The PAA allows for the expending development projects in the period when expenses were incurred or when the development project was completed. On the other hand, the organization may capitalize development expenditures in the balance sheet after the development phase is completed and the economic usefulness of the product/technology has been determined. Until then it is permissible to capitalize them in the balance sheet as accruals. However, in the case of the IAS, a cost previously recognized as an expense cannot be subsequently capitalized as an intangible asset.

The choice between recognition of the development work, as intangible assets or period expenses, is an important factor signaling the success of commercializing $R \& D$ outcomes or tax optimization. The recognition of the development expenditure as an expense (cost) of the financial year can significantly reduce the positive financial result, leading even to a loss (which decreases tax burdens). On the other hand, disclosing development expenditures in the form of intangible assets can inform the investors about the success of the next step in the R\&D strategy. It is worth mentioning that in the case of IAS, the expenditure for R\&D incurred during the period is mandatorily disclosed in the financial statements.

According to Oswald [2008], smaller companies, due to the need for financing its activities, are more likely to disclose development work in the balance sheet, while larger companies that generate high tax revenues are seeking tax optimization tools and prefer reducing the tax liabilities by recognizing development costs as tax deductible expenses.

Entrepreneurship with a tendency to learn, search for new operational solutions is a kind of challenge, while registering for the financial reporting and tax control of the financial aspects of these activities can be even more challenging. The governments of countries strive through the EU strategy to connect science with business in order to commercialize research results. This, however, requires the updating of legal regulations in each country in order not to hinder the entrepreneur R\&D activity. What may be conducive to greater investment in R\&D, and thus combining science and business, is the involvement of scientists in management of business via the active role as a member of the board of directors and/or the supervisory board.

\subsection{Scientist participation on the board}

Louis et al. [1989] explored the entrepreneurial activity of university scientists in life science fields, determining five types of academic entrepreneurship stemming from university research: (1) engaging in large scale science through externally funded research projects; (2) consulting or knowledge transfer resulting in supplemental income; (3) gaining industry support for research; (4) generating intellectual property; and (5) new venture creation.

Białek-Jaworska and Gabryelczyk [2016] show that companies using R\&D in their business appreciate the significance of the scientists-founders' achievements 
(in accordance with the "star-scientist" concept by Zucker et al. [1998]), the board's managerial skills [Colombo, Grilli 2005] and patents [Niosi 2003]. Among factors important for R\&D cost reduction, they identify the business location and the proximity of university centers, and the access to the science and research infrastructure [Zucker et al. 1998]. Access to sources of financing for R\&D activity is also crucial [Lerner et al. 2003].

Lockett et al. [2003] found that the more common roles for university scientists in a venture based on their research were as senior manager, advisor, or technical director. Lundqvist and Middleton [2013] also add the roles of inventor, co-founder and board member, but not necessarily lead entrepreneurial roles as regards venture creation. In these roles they advise, develop, legitimize and connect specific ventures with internal and external university resources, including students as key drivers. Scientists' participation in the supervisory board may be helpful in associating specialist knowledge with the needs of companies looking for solutions to the products developed themselves. The co-operation with partners may also help monetize those R\&D results that have not been used internally [Białek-Jaworska, Gabryelczyk 2016]. Thus, we can state the hypothesis: H1. Companies with a scientist on the supervisory board are likely to invest more in $R \& D$ for commercialization.

As for Poland, Białek-Jaworska and Gabryelczyk [2016] conducted qualitative research of scientists' role in a new biotech venture creation (as members of the management board) and consulting when sitting on the supervisory board. Analyzing the business models, they identify an important component specific to companies conducting R\&D activities: ensuring the firm's survival activities by funding research grants to make $R \& D$ possible prior to commercialization. This highlights the importance of financial constraints and government subsidies for the R\&D activity of companies established by scientists. Therefore, we formulate hypothesis H2. Companies with a scientist on the management board are likely to be more financial constrained.

We expect that the investment in increasing $R \& D$ depends on access to finance as public subsidies are a crucial incentive to attract private spending on R\&D. This is confirmed by the crowding-out effect well described in the literature.

\section{Research design}

To investigate the participation of scientists on the board, taking into account additional conditions, i.e. the impact of financial constraints on R\&D, we modify an investment model from Brown et al. [2009] for Bond et al. [2005] based on the dynamic optimization of the Euler equation for imperfectly competitive firms that accumulate productive assets with quadratic adjustment cost technology. To apply the model to $\mathrm{R} \& \mathrm{D}$, profits are considered as a function of the accumulated stock of R\&D scaled by fixed assets. We use assume that the adjustment costs of R\&D are quadratic in the ratio of R\&D-to-fixed assets. The Euler equation leads to the following empirical specification in the absence of financing constraints: 


$$
\text { rdexpen }_{i, t}=\beta_{0}+\beta_{1} \text { rdexpen }_{i, t-1}+\begin{gathered}
\beta_{2} \text { rdexpen }_{i, t-1}^{2}+\beta_{3} \text { sale }_{i, t-1}+\beta_{4} \text { cash flow }_{i, t-1}+ \\
d_{t}+\alpha_{i}+v_{i, t,}
\end{gathered}
$$

where: rdexpen $_{i, t}$ is R\&D spending for firm $i$ in the period $t$; sale sit, $_{\text {is firm sales; }}$ and cash flow ${ }_{i, t}$ denotes cash flow from operation scaled by total assets, the flow of internal funds defined consistent with previous literature on financing R\&D.

The initial model includes firm effects $\left(\alpha_{i}\right)$ and time effects $\left(d_{t}\right)$. If firms satisfy the Euler equation period by period, and use all information dated $t-1$ or earlier to form rational expectations, the residual term $\left(v_{i, t}\right)$ will be an independently and identically randomly distributed forecast error. The model implies that $\beta_{1}$ is positive and $\beta_{2}$ is negative; and $\beta_{3}$ is positive under imperfect competition. The lagged cash flow-to-asset ratio appears in the model to account for the cost of other factors of production, under constant returns to scale, and with the assumption that the marginal products of other factors equal their costs. As such, cash flow enters the specification even without financing constraints, but the structural model implies that the coefficient $\left(\beta_{4}\right)$ is negative. To explore the role of financing constraints on R\&D we add variables that correspond to the firm's access to internal equity, cash holdings and subsidies. We add contemporaneous cash flow as the standard measure of internal equity financing and contemporaneous sales as an additional control for firm demand. The modified regression equation with multiplicative dummy variable next to the financial constraint variables is:

$$
\begin{gathered}
\text { rdexpen }_{i, t}=\beta_{0}+\beta_{1} \text { rdexpen }_{i, t-1}+\beta_{2} \text { rdexpen }_{i, t-1}+\beta_{3} \text { am } \times \text { cash flow }_{i, t}+\beta_{4} \text { am } \times \\
\text { cash flow } \text { flit-1 }_{5}+\beta_{5} \text { sale }_{i, t}+\beta_{6} \text { as }_{i, t}+\beta_{7} \text { am } \times \text { cash holdings }_{i, t}+ \\
\beta_{8} \mathbf{a m} \times \text { grants }_{i, t}+\beta_{9} \text { family_firm }_{i, t}+\beta_{10} \text { controls }_{i, t}+\varepsilon_{i, t}
\end{gathered}
$$

To distinguish the role of a scientist in the management (am) board from his advising role in the supervisory board (as) we estimate the regression equation with the multiplicative dummy variable am next to the cash flow, cash holdings, grants. We add also the multiplicative dummy variable am next to the corporate governance scheme of family firm (control variable). Next, we split the data of our research sample into firms with a scientist on the management and/or supervisory board (as evidence of academic entrepreneurship) and other companies established by people outside the universities. We use the tobit panel method to estimate the non-linear regression model with panel-level random effects $y_{i t}=\beta x_{i t}+v_{i}+\varepsilon_{i, t}$ for $i=1, \ldots, n$ panels, where $t=1, \ldots, n, v_{i}$ - random effects, $\varepsilon_{i, t}$ - errors, where:

rdexpen $_{i, t}$ is R\&D spending for firm $i$ in the period $t$ capitalized in the assets scaled by fixed assets;

cash_flow is operational cash flow scaled by total assets;

sale is the natural logarithm of sales volume;

as is a dummy variable that takes the value of 1 if a scientist sits on the supervisory board, and 0 otherwise; 
am is a dummy variable that takes the value of 1 if a scientist sits on the management board, and 0 otherwise;

cash_holdings covers corporate cash resources measured by the cash and shortterm financial assets scaled by assets;

grants - subsidies for fixed assets and intangible assets recognized in the liabilities in the balance sheet as the value of long-term other deferred income scaled by assets.

We also include control variables:

$a c$ is a dummy variable that takes the value of 1 if a scientist sits on the management or supervisory board, 2 if scientists sit on the management and supervisory board, and 0 otherwise;

patent is a dummy variable that takes the value of 1 if a company has got at least one patent (on the basis of the Polish Patent Office's data), and 0 otherwise;

growth_opportunity is the growth rate of sales revenue year to year;

risk - operational risk proxied by standard deviation of operational cash flow for the last three years of operational cash flow scaled by total assets;

family_firm - a dummy variable equals 1 if a member of the management board of a limited liability company is a shareholder in this company, and 0 otherwise.

\section{Research sample and findings}

The sample consists of roughly 172,515 observations over the period 2003-2013 for 18,125 Polish private limited liability companies and joint stock companies. To create our sample, we merge time-series observations on firm-level R\&D investment capitalized in their assets and other firm characteristics from financial statements with data on IP protection and data on members of company boards and shareholders. As a proxy for IP protection, we use data on patents owned by firms. Next, we collect data on shareholders, members of management board and supervisory board of companies with the use of an application dedicated to retrieved data from the Polish National Court Register. Finally, we merge this data with data on scientists collected from the Polish Scientists Database (POLON) website register.

Table 1 shows the industry distribution of our research sample and the structural characteristics of the companies analyzed, including their legal form, R\&D outcomes ready for commercialization capitalized in the assets, use of IP protection (patents), and participation of a scientist in the management or supervisory board.

Table 2 presents the findings of the regression equations estimation. The coefficient of the lagged variable of expenditure on R\&D is positive, and the lagged variable expenditure on $R \& D$ raised to the square is negative in all models. This is consistent with the results of Brown et al. [2009] and Brown and Petersen [2011], although the absolute value of $\beta_{2}$ coefficients are much lower than 1 , except for model 3 of companies with a scientist on the board. This indicates that companies with a strong scientist influence on doing business (via a seat on a management 
board) are more willing to perform $R \& D$ projects and commercialize the $R \& D$ outcomes due to the opportunities to lower $\mathrm{R} \& \mathrm{D}$ costs through research cooperation with university centers and access to their science and research infrastructure. The results for the presence of a scientist on a supervisory board (as) confirm hypothesis H1 that companies supervised and advised by a scientist are likely to invest more on the commercialized results of R\&D activity. Private companies that conduct R\&D activity resulting in patents are also likelier to invest more in $R \& D$ outcomes ready for commercialization.

Table 1. Structure of research sample

\begin{tabular}{|l|l|c|c|}
\hline \multicolumn{1}{|c|}{ Characteristics } & \multicolumn{1}{|c|}{ Description } & Observations & Share (\%) \\
\hline PKD 10-33 & Manufacturing (high-tech) & 88.113 & $51 \%$ \\
\hline PKD 35 & Electricity & 5.418 & $3 \%$ \\
\hline PKD 38-39 & Waste management & 4.758 & $3 \%$ \\
\hline PKD 6 & Information \& communication & 41.011 & $24 \%$ \\
\hline PKD 7 & Professional, scientific \& technical services & 32.581 & $19 \%$ \\
\hline & total research sample & $\mathbf{1 7 2 . 5 1 5}$ & $\mathbf{1 0 0 \%}$ \\
\hline legal form & Limited liability company & 156.781 & $91 \%$ \\
\hline & Joint stock company & 15.625 & $9 \%$ \\
\hline other characteristics & R\&D outcomes capitalized in the assets & 10.725 & $6 \%$ \\
\hline & IP protection & 5.807 & $3 \%$ \\
\hline & Scientist on management board & 27.198 & $16 \%$ \\
\hline & Scientist on supervisory board & 13.548 & $8 \%$ \\
\hline
\end{tabular}

Source: own elaboration.

Table 2. Determinants of corporate R\&D activity - results of the tobit panel models

\begin{tabular}{|l|c|c|c|c|}
\hline & $\begin{array}{c}(1) \text { total } \\
\text { sample }\end{array}$ & $\begin{array}{c}\text { (2) total } \\
\text { sample }\end{array}$ & $\begin{array}{c}\text { (3) scientist on } \\
\text { the board }\end{array}$ & $\begin{array}{c}\text { (4) no scientist } \\
\text { on the board }\end{array}$ \\
\hline rdexpen_lag & 2 & 3 & 4 & 5 \\
\hline rdexpen_lag2 & $0.2785^{* * *}$ & $0.2787 * * *$ & $0.7437^{* * *}$ & $0.2192^{* * *}$ \\
& $(0.0020)$ & $(0.0020)$ & $(0.0106)$ & $(0.0018)$ \\
\hline cash_flow & $-0.0116^{* * *}$ & $-0.0117^{* * *}$ & $-0.6698 * * *$ & $-0.0092^{* * *}$ \\
& $(0.0001)$ & $(0.0001)$ & $(0.0121)$ & $(0.0001)$ \\
\hline am\#cash_flow & $0.0006^{* * *}$ & $0.0006^{* * *}$ & 0.0003 & $0.0006^{* * *}$ \\
& $(0.0002)$ & $(0.0002)$ & $(0.0003)$ & $(0.0001)$ \\
\hline cash_flow_lag & $0.0006 \#$ & $0.0006 \#$ & & \\
& $(0.0004)$ & $(0.0004)$ & & $-0.0003 * *$ \\
& $-0.0004 * *$ & $-0.0004 * *$ & 0.0001 & $(0.0001)$ \\
\hline
\end{tabular}


Table 2, cont.

\begin{tabular}{|c|c|c|c|c|}
\hline 1 & 2 & 3 & 4 & 5 \\
\hline am\#cash_flow_lag & $\begin{array}{l}-0.0003 \\
(0.0004)\end{array}$ & $\begin{array}{l}-0.0003 \\
(0.0004)\end{array}$ & & \\
\hline sale & $\begin{array}{c}0.0002 * * * \\
(0.0000)\end{array}$ & $\begin{array}{c}0.0002 * * * \\
(0.0000)\end{array}$ & $\begin{array}{c}0.0001 * * \\
(0.0001)\end{array}$ & $\begin{array}{c}0.0002 * * * \\
(0.0001)\end{array}$ \\
\hline as & $\begin{array}{c}0.0004 \# \# \\
(0.0003)\end{array}$ & $\begin{array}{c}0.0006^{* *} \\
(0.0003)\end{array}$ & $\begin{array}{c}0.0003 \# \# \\
(0.0002)\end{array}$ & \\
\hline patent & $\begin{array}{c}0.0048 * * * \\
(0.0004) \\
\end{array}$ & $\begin{array}{c}0.0048 * * * \\
(0.0004) \\
\end{array}$ & $\begin{array}{c}0.0017 * * * \\
(0.0005)\end{array}$ & $\begin{array}{c}0.0050^{* * *} \\
(0.0004) \\
\end{array}$ \\
\hline cash_holdings & $\begin{array}{c}-0.0006^{* *} \\
(0.0003)\end{array}$ & $\begin{array}{l}-0.0006^{*} \\
(0.0003)\end{array}$ & $\begin{array}{c}-0.0007 \# \# \\
(0.0005)\end{array}$ & $\begin{array}{c}-0.0006^{* *} \\
(0.0003)\end{array}$ \\
\hline am\#cash_holdings & $\begin{array}{c}-0.0011^{*} \\
(0.0006)\end{array}$ & $\begin{array}{c}-0.0012 * \\
(0.0007)\end{array}$ & & \\
\hline$(\mathrm{ac}=0) \#$ grants & $\begin{array}{l}0.0017 * \\
(0.0010) \\
\end{array}$ & & & \\
\hline$(\mathrm{ac}=1) \#$ grants & $\begin{array}{c}0.0153 * * * \\
(0.0020) \\
\end{array}$ & & & \\
\hline$(\mathrm{ac}=2) \#$ grants & $\begin{array}{c}0.0092 \# \# \\
(0.0060)\end{array}$ & & & \\
\hline$(\mathrm{am}=0) \#$ grants & & $\begin{array}{c}0.0030^{* * *} \\
(0.0010)\end{array}$ & & \\
\hline$(\mathrm{am}=1) \#$ \#rants & & $\begin{array}{c}0.0127 * * * \\
(0.0022)\end{array}$ & & \\
\hline grants & & & $\begin{array}{c}0.0094 * * * \\
(0.0014)\end{array}$ & $\begin{array}{l}0.0014 * \\
(0.0008) \\
\end{array}$ \\
\hline growth_opportunity & $\begin{array}{c}-0.0002 * \\
(0.0001) \\
\end{array}$ & $\begin{array}{c}-0.0002 * \\
(0.0001) \\
\end{array}$ & $\begin{array}{c}-0.0005^{*} \\
(0.0003)\end{array}$ & $\begin{array}{l}-0.0001 \\
(0.0001) \\
\end{array}$ \\
\hline family_firm & $\begin{array}{l}-0.0001 \\
(0.0001)\end{array}$ & & $\begin{array}{l}0.0003 * \\
(0.0002)\end{array}$ & $\begin{array}{c}-0.0002 * \\
(0.0001)\end{array}$ \\
\hline risk & $\begin{array}{c}0.0002 \\
(0.0003)\end{array}$ & $\begin{array}{c}0.0002 \\
(0.0003)\end{array}$ & $\begin{array}{c}0.0007 \# \# \\
(0.0005)\end{array}$ & $\begin{array}{c}0.0002 \\
(0.0003)\end{array}$ \\
\hline _cons & $\begin{array}{c}-0.0019 * * * \\
(0.0005)\end{array}$ & $\begin{array}{c}-0.0020 * * * \\
(0.0005)\end{array}$ & $\begin{array}{c}-0.0011 \# \\
(0.0008)\end{array}$ & $\begin{array}{c}-0.0020 * * * \\
(0.0005)\end{array}$ \\
\hline Number of observations & 86,731 & 86,731 & 17,237 & 67,649 \\
\hline Number of groups & 18,125 & 18,125 & 3,187 & 14,605 \\
\hline LR test & $7220.46 * * *$ & $7209.49 * * *$ & $31.76^{* * *}$ & $8046.14 * * *$ \\
\hline
\end{tabular}

Standard errors in parentheses. \# $p<0.2$, \#\# $p<0.15, * p<0.1, * * p<0.05$, *** $p<0.01$. Source: own elaboration. 
In addition, the results indicate a strong, positive relationship between corporate investment in R\&D activity and government subsidies (grants for tangible and intangible assets). In particular this relationship is more significant and stronger in companies with a scientist on their management or supervisory board (much higher $\beta_{8}$ coefficient for ac $>0$ in model 1). The cash flow lagged variable is significant only in the case of companies with no scientists on the management board (models 1-2 for $a m=0)$ and also on the supervisory board (model 4). In companies with a scientist on the management board (models 1-2) the decrease in corporate cash holdings determines the higher increase in expenditures on $R \& D$, the results of financing this business from cash resources because of the high information asymmetry and uncertainty associated with $R \& D$ activity. These findings indicate that financial constraints are a more important limitation for $\mathrm{R} \& \mathrm{D}$ investments of companies with a scientist on their management board, according to $\mathrm{H} 2$.

Moreover, companies with scientists on the board that have lower growth opportunities tend to increase spending on the R\&D outcomes for commercialization (models 1-3 compared to model 4). This may be due to the instability of revenue from sales and/or problems with sales channels. The reason may also be a lack of experience in running a business - the commercialization of research results without the proper identification of customer segments and/or building relationships with customers. For the subsample of firms without scientists on the board, the growth opportunity variable was insignificant (model 4). A higher risk (variability of cash flow) positively influences investment in the R\&D outcomes of companies with a scientist on the board (model 3). However, this effect is less significant. On the one hand, this may be due to the relatively higher uncertainty related to the R\&D activity conducted by young, small and inexperienced enterprises managed by a scientist. On the other hand, this difference could be explained by the different risk management strategies conducted by family firms with relatively fewer significant agency costs. As the coefficient at the family firm variable is positive in model 3 for companies with a scientist on the management/supervisory board, contrary to the negative coefficient in the case of companies with no scientist on the board (model 4). Family firms with scientists on the management board (model 3) are likelier to invest more in the $\mathrm{R} \& \mathrm{D}$ outcomes ready for commercialization than companies with no scientist on the board (model 4).

\section{Conclusions}

Companies with scientists on the supervisory board are likely to invest more in R\&D for commercialization. However, companies with a scientist on the management board are likely to show more financial constraints, because their increase strongly depends on access to finance. Therefore, an increase in spending on R\&D requires public support and the promotion of cooperation between science and business, striving towards the realization of implementation research. Our findings could support policymakers to construct an evidence-based policy intended to boost the 
commercialization of the R\&D outcomes. Our study allows policymakers and foreign investors to learn the needs and problems of companies established by scientists that are interested in technology and knowledge transfer from universities to the market place. Financial constraints are a more important limitation for R\&D investment in companies with a scientist on their management board due to the lack of sufficient internal finance and cash holdings. Government subsidizing of investment related to $R \& D$ is more important for companies with a scientist on their management board. Significant sources of financing R\&D outcomes are internal equity and grants for research and infrastructure, particularly in companies managed by scientists.

Companies with scientists on the board and lower growth opportunities increase spending on the commercialization of the R\&D outcomes. This means that they invest more in R\&D when their sales decrease. In addition, family businesses in which there are scientists on the board are more likely to invest in R\&D for the commercialization of their research results, contrary to companies operating outside academia. This means that family businesses with scientists' engagement in the management board can be called "dynamic enterprises" according to the model of J. Schumpeter. This type of organizations has a direct impact on building a knowledgebased economy, and thus they should be supported by the authorities systematically.

The results of our study could encourage companies to cooperate with scientists in doing business on a basis of the results of their research. This knowledge could also assist policymakers, investors, managers and scientists in effectively combining science with business and move R\&D closer to the socially optimal level in those countries that are catching-up, such as Poland. The limitation of this study is the lack of data on research activity costs that are not recognized in the assets. Thus, we can see potential directions for further studies. Future research could deal with comparative analyses between countries of the Visegrad Group.

\section{Bibliography}

Adamczyk A., 2013, Inwestycje $w$ badania i rozwój przedsiębiorstw w świetle badań ankietowych, Wiadomości Statystyczne, vol. 1.

Białek-Jaworska A., 2016, 'A scientist in the board' effect on recognition of $R \& D$ outcomes in private firms' reports, Accounting and Management Information system, vol, 15, no. 4, pp. 683-709.

Białek-Jaworska A., Gabryelczyk R., 2016, Biotech spin-off business models for the internationalization strategy, Baltic Journal of Management, vol. 11, no. 4, pp. 380-404.

Białek-Jaworska A., Grabińska B., 2017, Under-reporting of corporate R\&D expenditure in Polandconsequences for verifying possible crowding-out effect of private investment by public subsidies. Evidence from Polish pharmaceutical sector, Proceedings of the 12th International Conference Accounting and Management Information Systems 2017.

Bond S., Harhoff D., Van Reenen J., 2005, Investment, R\&D and financial constraints in Britain and Germany, Annales d'Économie et de Statistique, vol. 79/80, pp. 433-460.

Brines S., Shepherd D., Woods Ch., 2013, SME family business innovation: exploring new combinations, Journal of Family Business Management, vol. 3, issue 2, pp. 117-135. 
Brown J., Fazzari S.M., Petersen B.C., 2009, Financing innovation and growth: cash flow, external equity, and the 1990s R\&D boom, Journal of Finance, vol. 64, no. 1, pp. 151-185.

Brown J., Petersen B.C., 2011, Cash holdings and R\&D smoothing, Journal of Corporate Finance, vol. 17 , no. 3 , pp. $694-709$.

Bryła P., Jurczyk T., Domański T., 2013, Korzyści wspótpracy uczelni wyższych z otoczeniem gospodarczym - próba typologii, Marketing i Rynek, 4, pp. 14-19.

Colombo M.G., Grilli L., 2005, Founders' human capital and the growth of new technology-based firms: a competence-based view, Research Policy, vol. 34, no. 6, pp. 795-816.

Drabińska D., 2012, Innowacyjność gospodarki w wymiarze współczesnym $i$ w ujęciu historycznym, Kwartalnik Kolegium Ekonomiczno-Społecznego, Studia i Prace, vol. 2, pp. 9-25.

Drucker P.F., 1999, Społeczeństwo prokapitalistyczne, PWN, Warszawa.

Endres A.M., Woods Ch.R., 2010, Schumpeter's conduct model of the dynamic entrepreneur: scope and distinctiveness, Journal of Evolutionary Economics, vol. 20, Issue 4, pp. 583-607.

Firmy rodzinne $w$ Polsce, 2018, https://www.forbes.pl/biznes/firmy-rodzinne-w-polsce/26mxttx, access: 10.08 .2018 .

Koźmiński A.K., 2001, Jak tworzyć gospodarkę oparta na wiedzy?, [in:] Strategia rozwoju Polski u progu XXI wieku, Kancelaria Prezydenta RP i Komitet Prognoz Polska 2000 plus, PAN, Warszawa.

Koźmiński A.K., 2004, Zarzadzanie w warunkach niepewności, Wyd. Nauk. PWN, Warszawa.

Kukliński A., 2001, Gospodarka oparta na wiedzy. Wyzwania dla Polski XXI wieku, Warszawa.

Lerner J., Shane H., Tsai A., 2003, Do equity financing cycles matter? Evidence from biotechnology alliances, Journal of Financial Economics, vol. 67, no. 3, pp. 411-446.

Lockett A., Wright M., Franklin S., 2003, Technology transfer and universities' spin-out strategies, Small Business Economics, vol. 20, no. 2, pp. 185-200.

Louis K.S., Blumenthal D., Gluck M.E., Stoto M.A., 1989, Entrepreneurs in academe: an exploration of behavior among life scientists, Administrative Science Quarterly, vol. 34, no. 1, pp. 110-131.

Lucas R.E., 1988, On the mechanics of economic development, Journal of Monetary Economics, vol. 22.

Lundqvist M.A., Middleton K.L.W., 2013, Academic entrepreneurship revisited - university scientists and venture creation, Journal of Small Business and Enterprise Development, vol. 20, no. 3. pp. 603-617.

McCann G., DeMoss M., Dascher P., Barnett S., 2003, Educational needs of family businesses: perceptions of university directors, Family Business Review, 16, pp. 437-456.

MSR 38 Wartości niematerialne, Dz. U. Komisji Europejskiej z 29 listopada 2008 r., poz. L 320/252.

Niklewicz-Pijaczyńska M., 2018, Od koncepcji gospodarki opartej na wiedzy do nowej strategii rozwoju UE 2020, http://www.bibliotekacyfrowa.pl/Content/35524/021.pdf, access: 15.07.2018.

Niosi J., 2003, Alliances are not enough for explaining rapid growt in biotechnology firms, Research Policy, vol. 32, no. 5, pp. 737-750.

OECD - World Bank Institute, 2000, Korea and the Knowledge Based Economy. Making the Transition, Paris.

Oswald D.R., 2008, The determinants and value relevance of the choice of accounting for research and development expenditures in the United Kingdom, Journal of Business Finance \& Accounting, vol. 35 , no. 1-2.

Perspektywa 2014-2020: wspólpraca biznesu z nauka i innowacje, http://klasterip.pl/perspektywa2014-2020-wspolpraca biznesu-z-nauka-i-innowacje/, access: 10.08.2018.

Romer P., 1994, The origins of endogenous growth, Journal of Economic Perspectives, vol. 8, no. 1.

Schumpeter J.A., 1960, Teoria rozwoju gospodarczego, PWN, Warszawa.

Skrzypek E., 2008, Miejsce i znaczenie wiedzy w zrównoważonym rozwoju, [w:] Filozofia TQM w zrównoważonym rozwoju, ed. J. Żuchowski, Wydawnictwo Politechnika Radomska, Radom.

Skrzypek A., 2009, Uwarunkowania kreatywności pracowników wiedzy w warunkach społeczeństwa wiedzy, [in:] Kreatywność i przedsiębiorczość w projakościowym myśleniu i działaniu, red. E. Skrzypek, Wyd. UMCS, Lublin. 
Skrzypek E., 2011, Gospodarka oparta na wiedzy i jej wyznaczniki, Nierówności Społeczne a Wzrost Gospodarczy, 23, pp. 270-280.

Ustawa z dnia 29 września 1994 r. o rachunkowości, Dz. U. 2018.0.395, tekst jednolity.

Zucker L.G., Darby M.R., Brewer M.B., 1998, Intellectual human capital and the birth of US biotechnology enterprises, The American Economic Review, vol. 88, no. 1, pp. 290-305.

\section{WYDATKI NA B+R I ROLA NAUKOWCÓW}

Streszczenie: Gospodarka oparta na wiedzy wymaga regularnej współpracy nauki z biznesem. Jest to możliwe dzięki spółkom, które tworzą i wdrażają innowacje. Artykuł koncentruje się na rozpoznaniu wydatków na $\mathrm{B}+\mathrm{R}$ w świetle regulacji rachunkowości. Celem artykułu jest zbadanie, czy spółki z naukowcami w zarządzie są bardziej skłonne inwestować w badania i rozwój. Przeprowadzono analizę tobitową danych panelowych z rocznych sprawozdań finansowych ponad 18000 polskich przedsiębiorstw niepublicznych powiązanych $\mathrm{z}$ danymi o patentach oraz o naukowcach zatrudnionych na uczelniach. Wyniki wskazują, że przedsiębiorstwa z naukowcami w radach nadzorczych są skłonne inwestować w B+R. Jednak nakłady na B+R są narażone na ograniczenia finansowe. Ich wzrost zależy od dostępu do źródeł finansowania. Dlatego instytucje w Polsce powinny wspierać współpracę nauki $\mathrm{z}$ biznesem. Takie podejście wymaga zaktualizowanych przepisów $\mathrm{w}$ dziedzinie rachunkowości, dotyczących ujmowania nakładów i wyników działalności B+R.

Słowa kluczowe: $B+R$, dynamiczna przedsiębiorczość, akademicka przedsiębiorczość, innowacje, naukowiec, firma rodzinna. 